\title{
THE INFLUENCE OF VALUE CLARIFICATION TECHNIQUE (VCT) LEARNING MODEL ON HOMELAND ATTITUDE AT ELEMENTARY SCHOOL
}

\author{
Anantama Dewantoro, Kus Eddy Sartono
}

\begin{abstract}
Це дослідження має за мету вивчити вплив учбової моделі Техніки Виявлення Цінності на відчуття любові до Батьківщини на четвертому ступені початкової школи або SekolahDasar (SD) в Індонезії. Дослідження було здійснено в мікрорайоні SD Negeri 1 Karangmoncol PurbalinggaKarangsari, використовуючи квазі-експериментальне дослідження на прикладах нееквівалентного дизайну контрольної групи. Це дослідження використовує дві групи: експериментальну - із застосуванням учбової моделі Техніки виявлення цінності та контрольну модель - без преференціального навчання. Результати дослідження свідчать про те, що: 1) почуття любові до Батьківщини студентів четвертого ступеня демонструються учбовою моделлю Техніки Виявлення Цінності, 2) в наявності модель взаємодії навчання та почуття любові до Батьківщини, 3) почуття любові до Батьківщчини при застосуванні учбової моделі Техніки Виявлення Цінності вище, ніж у студентів кооперативної моделі навчання. Дане дослідження демонструє, що почуття любові до Батьківщини у групі Техніки Виявлення Цінності та контрольній суттєво різняться

Ключові слова: Техніка Виявлення Цінності, почуття любові до Батьківщчни, студенти четвертого ступеня початкової школи
\end{abstract}

Copyright (C) 2019, Anantama Dewantoro, Kus Eddy Sartono. This is an open access article under the CC BY license (http://creativecommons.org/licenses/by/4.0).

\section{Introduction}

In the era of globalization, every country must be able to compete with other countries. Countries that cannot compete will be far behind other countries. In the face of such competition required quality Human Resources (HR). Qualified human resources are cerim inan of education carried out in the country. Education is closely related to the learning process. A good learning process is an implementation in accordance with the standard processes in the education unit. To achieve the learning objectives, the teacher needs to know, understand, apply basic concepts in the learning process. The ability to understand/comprehend has been mastered if it can be explained in its own words, can compare, can distinguish, and can contrast [1].

In addition, education in essence does not only form intelligent Indonesian people, but also personality or character. This is in accordance with Law No. 20 of 2003 concerning the National Education System in Article 3 , which reads as follows, national education functions to develop capabilities and shape the character and civilization of a dignified nation in order to educate the nation's life. National education aims to develop the potential of students to become human beings who have faith and are devoted to God Almighty, have good character, are healthy, knowledgeable, capable, creative, independent, and become democratic and responsible citizens.

One of the founding fathers of the nation, the first president of the Republic of Indonesia, This nation must be built by prioritizing character building because character building will make the Indonesian nation a large, advanced and glorious, dignified nation [2]. If this char- acter building is not carried out, then the Indonesian nation will become a coolie nation.

Reflecting on the functions and objectives of national education, also the statement of Ir. Soekarno above, it is clear that education at every level, including elementary schools or Sekolah Dasar (SD) in Indonesian, must be carried out systematically in order to achieve national education goals that are based on the breath of character. It aims to realize students who have character so that they are able to compete, ethical, moral, polite and interact with the community. The school institution is the second educational institution after the family, which has an important role in the formation and development of knowledge, skills and personality. Schools are a very strategic place for character education, because children from all walks of life will receive education in schools [3].

Ironic is the right word to describe the crisis that is affecting our nation's successors, even though the burden to advance this beloved homeland is on their shoulders. The rapid flow of globalization has become one of the causes of the erosion of the value of patriotism in the soul of the younger generation. Many parents complain their children are addicted to modern games [4]. Children are closer to games, lazy to learn, and hard-headed. Even violence is carried out by children because it is inspired by the game. Referring to the news above the fading value of homeland love in the younger generation can also be seen when the younger generation now understands online games more than traditional games. Many young people who prefer online games rather than have to play traditional games, even they do not know how to play traditional games. 
Efforts to instill the value of patriotism are not as easy as discussed or discussed. The purpose and material values of patriotism in schools need to be carefully designed to give birth to a new civilization that puts the interests of the homeland above personal interests and shapes student personalities that reflect Pancasila, especially when in the school environment.

Based on observations and interviews of fourth grade teacher at SDN 1 Karangsari, obtained $\mathrm{f}$ deed in the field showed lack of attention and seriousness students in participating in the flag ceremony on Monday. In these activities, many students seemed to joke and did not understand the meaning or meaning of the ceremony. This results in the lack of solemnity of students in attending the flag ceremony.

Student knowledge and experience in playing traditional games or singing folk songs is lacking. Many reason students are rarely taught or the local games and songs are outdated, boring and the language used is difficult to understand. Students are more enthusiastic about singing dangdut songs and playing online games. There are still students who fight because they are bullied by their friends or because they have different opinions.

Some of the examples above clearly show that Indonesian culture is now starting to fade. Therefore the government together with educators and parents as well as community support must pay attention to education which also focuses on the affective domain. The affective domain is meant to enhance the morality, norms, values and love of the motherland in society. Attitude is a reflection of a person's feelings or conditions before committing, so this attitude can also be said to be a person's threshold before committing an action. The attitude that is most needed for the present and the future is the attitude of loving the motherland. The love of the motherland is a sense of loving the country from every element that is manifested in daily life.

An education should create a good learning arrangement. In the sense that students feel comfortable and feel at home following learning activities. In addition, now there are also some very innovative learning models. In doing so, learning also requires skilled and creative educators to make some of these learning models enjoyable.

However, in its implementation, a learning model must be chosen. When choosing a learning model also must consider the objectives of the learning activities to be carried out. Thus learning not only requires students to memorize, but also requires students to be able to understand concepts well, so that they are able to behave wisely in solving problems that exist in everyday life.

VCT is a model that tries to help answer some problems and build value systems [5, 6]. It means that VCT helps to clarify or clarify the values of students in life through problem solving, discussion, dialogue and presentations. In this way students discover for themselves the values they think are most appropriate in accordance with their believed values without coercion from others.

The hallmark of learning with VCT is a conflict of values or decisions in a dilemma case. Contemplation and conflict; That is, in learning that with VCT students are faced with an atmosphere of contemplation and con- flict [7]. The technique of contemplation and conflict is a reflective method that asks students to consider something they believe to be true (contemplation).

Learning with VCT is based on the principle of moral relativity $[8,9]$. That is, VCT is a value learning model that shows that people's opinions are not the same. This is very much influenced by the different stages of moral development of people. Students are directed to appreciate the relativity of values through learning that contains moral dilemmas. Therefore it is very appropriate if VCT is used to shape students' tolerance attitude. Tolerance is behavior that leads to mutual respect for differences.

The purpose of VCT is to help students become more focused, more productive, sharpen critical thinking and help students to establish relationships with others $[10,11]$. In line with that, the purpose of VCT is to assist individuals or groups in clarifying and actualizing based on their own values [11]. Meanwhile according to Wijayanti [1] the purpose of VCT is to measure or find out student awareness about the value of fostering student awareness about its value; instill value to students and train students how to assess, accept and make decisions on an issue.

On another occasion, the purpose of VCT was not only to instill a certain set of values [10]. VCT helps students utilize the process of assessing in making decisions. More emphasis on decision making based on the steps in VCT [10]. This is what distinguishes. VCT allows students to test the difference between what is assessed and what is said.

Broadly speaking, the implementation of learning using VCT begins with the group representative choosing the problem that the group wants to solve (valuing); then each group discusses the problem they have chosen and besides that also looks for other alternative solutions to resolve the problem (choose); and finally write the solution to the problem on the chosen confidence card. In addition, group representatives must express their group's opinion in front of the class in order to be responsible for the results of the discussion.

In its implementation, a teacher must have full confidence in his students, so that learning activities carried out using the VCT model can achieve the expected target of learning to the maximum. The basic thoughts that must be owned by the teacher,include [12]:

a) students have the same intellectual abilities;

b) all students are able to be honest;

c) all students have the same interests;

d) students have a willingness to change; at hand.

e) students have a desire to solve the problem

The love of the motherland, the attitude of patriotism was the spirit of the struggle of the heroes and the reintroduction of Indonesian heroes compared to heroes from abroad which incidentally had nothing to do with the struggle of the Indonesian nation [13]. As part of the attitude of patriotism, the lives and struggles of heroes should still be instilled against students. Planting can be passed with many things, such as; ceremony, song of struggle, history of struggle etc.

Many things can be done in terms of showing love for the motherland, both in the form of interaction / atti- 
tude towards the Indonesian people, thinking about Indonesia and acting that reflects the Indonesian nation. Love for the motherland is not just as explained above, because love for the motherland will not be separated from the attitude of Nationalism. Nationalism is an unwritten force and can be formed in an education system [14]. Through education it is pervasive and often unwritten in shaping the education system.

This opinion is complemented, who states that nations inspire love, and often profoundly self-affirming love [15]. The cultural products of nationalism-poetry, process fiction, music, music, plastic arts - show this love very clearly in thousand of different forms and styles. That the love of the State of each individual has different things as in the result of nationalism by making poetry, prose fiction, musih and a work of art.

Attitude of patriotism that is when a person whose behavior or actions are in accordance with the characteristics or indicators on the attitude of patriotism. Homeland love is a political aspect which will lead to ethnic and cultural equality [11]. This results in the discussion becoming more complex. The unity and unity of a country is marked by equal rights and obligations of citizens.

The development of patriotism in a person can be explained by the following, including strong positive national emotions; high-intensity national behavior; very positive beliefs about the state and people [16]. When someone has shown such things, his life will be preoccupied with thinking and doing positive things for the good of the surrounding environment.

The attitude of patriotism can be shown through the following indicators : patriotism; reward heroes' services; willing to sacrifice for the benefit of the nation and state; prioritizing unity and unity; reformer soul and do not know surrender, and; have a considerate attitude of fellow human beings [2].

As part of the love of the motherland has a type of Nationalist attitude according to explanation of five types of nationalism [15], namely;

1) national feeling (feeling of having one country);

2) national desires (like people from one country);

3) national pride (being proud of one with people and the country);

4) national preferences (choosing one person and country over others);

5) national superiority (the feeling of national attitudes possessed by citizens in the world even in Indonesia.

The indicator of patriotism in education is formulated that there are 18 character values. Training to strengthen character education began in 2010, following are indicators of patriotism taken from the Training Material guiding learning methodologies based on cultural values shaping the competitiveness and character of the nation.

Indicators of patriotism are explained in simpler language. The indicators include: respecting the services of national heroes, proud of using domestic products; respect the natural beauty and the Indonesian landscape; memorize the national songs, and; choose to travel within the country [16].

Based on the opinion of the experts above, it can be concluded that the indicators of patriotism that will be used in this study refer to Mustari's opinion. The consid- eration is the five indicators that are discussed in accordance with characteristics that are easily understood by elementary school children. In addition, these indicators are easy to use for grade IV elementary school children. These indicators include:

a) valuing the services of national heroes;

b) proudly using domestic products;

c) respect the natural beauty and culture of Indonesia;

d) memorize the national songs;

e) choose to travel in the country.

The attitude of patriotism cannot stand on its own as part of education to reach the golden generation proclaimed by the national government in 2025 . Therefore, the attitude of patriotism stands between nationalism and patriotism, that patriotism is part of the spirit of loving the motherland in their daily lives and becomes an individual attitude so that they are willing to sacrifice everything for the glory and prosperity of their homeland [2]. Patriotism is the soul and spirit of love for the motherland and can complement the existence of a nationalism [9]. Here there is a relationship that states that the spirit of loving the homeland is directly proportional to the Patriotism who is passionate about loving the homeland. Patriotism is part of nationalism in Indonesian Nationalism [13].

Any once things were able to evoke the spirit of love for the homeland, especially for the students through some innovative learning models such as VCT models. The thing that needs to be done is to make yourself available early to love and appreciate all the cultures that exist without discriminating or introducing their own culture because they are one, namely Indonesia. If the attitude of love of the motherland is high, then there is no need to worry anymore that the nation's cultural heritage will be well preserved and attacks from outside will be reduced by themselves because they are afraid to see unity and join hands in defending and defending Indonesia's independence.

Based on the background and study of the literature above, the problem can be formulated as follows how the influence of the VCT learning model on the attitude of loving the homeland of fourth grade students of the Karangmoncol Nusantara Elementary School From the formulation of the problem, the purpose of writing is to determine the effect of the Value Clarification Technique learning model on the loving attitude of the homeland of fourth grade elementary school students.

\section{Aim of research}

The aim of this study is knowing the influence of the learning model Value Clarification Technique against the attitude of the love on homeland in grade IV elementary school.

To achieve the set aim, the following tasks have been solved:

1. Knowing the concept of learning models of Value Clarification Techniques in elementary schools.

2. Knowing the concept of a mother's love attitude in elementary school.

3. Test effect the learning model of Value Clarification Techniques on the attitude of the love on homeland in elementary school. 


\section{Research Method}

\section{1. Method}

This study uses a quantitative approach to quasiexperimental research with a pattern of noneequivalent control group design. Three groups, namely two experimental groups and one comparison group (control) were included in it. The experimental group and the control group were considered homogeneous in terms of abilities and social background. The intended homogeneity includes: the three schools used in this study are public elementary schools that have recently applied or used the 2013 curriculum; the ability of the fourth grade teachers in the three schools is the same, because one generation when attending training for the implementation of the 2013 curriculum; the three teachers discussed each other in preparing their lesson plans; the ability of Grade IV students in the three schools is the same; and the location of schools that are close to one another.

Determination of the class that will be the experimental group and the control group is done by drawing. After the draw in SDN 1 Karangsari and SDN 1 Baleraksa the names appeared in the first and second ranks so that they became the experimental group, while SDN 1 Pepedan became the control group. This is done to avoid the subjectivity of researchers. Before the draw was made, it was certain that the three elementary schools did not use the previous VCT model .

The steps in the study are:

1) pre-experiment measurenment (measurement before treatment);

2) treatment (the act of carrying out the experiment / treatment giver);

3) post-experimental measurenment (measurement after treatment is given).

The experimental group was given treatment using the VCT model, while the control group used the lecture method.

The study was conducted in fourth grade students of the Kerangmoncol Purbalingga Nusantara Archipelago Elementary School, precisely in Karangsari 1 Primary School, Baleraksa 1 Primary School and Pepedan 1 Primary School. This research was conducted in semester 2 of the 2018/2019 school year, in March 2019.

\section{2. Population and Research Samples}

The population used in this study were all fourth grade students of the Nusantara cluster elementary school Karangmoncol Purbalingga in the 2018/2019 academic year consisting of 7 elementary schools.

The samples in this study were SD Negeri $1 \mathrm{Ka}-$ rangsari, SD Negeri 1 Baleraksa, and SD Negeri 1 Pepedan. The reason for choosing the three schools is because the ability of students from the three schools is the same, the facilities and infrastructure are also relatively similar, and the number of students is relatively the same.

\section{3. Data collection technique}

The data collection technique used in this study is Attitude Scale . Attitude scale is a collection of questions about an attitude object. From the subject's response to each question it can then be concluded regarding the direction and intensity of one's attitude [17]. In this study the attitude attitude that will be used is the Likert scale, on the Likert scale, the research subject is faced with the statements "positive" and "negative" and respondents are asked to state whether "strongly agree", "agree", "doubtful", " disagree ", and" strongly disagree ". This test itself will be carried out twice. This test is planned to be carried out before being given treatment and after being given a need.

The attitude scale is used to measure the attitude of loving the motherland. In this study, the attitude scale used is a Likert scale. Likert scale is used to measure the extent to which the attitude of love homeland owned by students in him. Furthermore, the variables to be measured using this scale are spelled out more specifically as indicator variables. The indicators of these variables can only be used as a reference in the preparation of instrument items in the form of positive and negative statements [18].

\section{4. Data analysis}

Descriptive analysis is used to analyze data by describing or describing data that has been obtained from the results of pre-test and post-test in the control and experimental groups. Descriptive analysis in this study was used to illustrate the effect of VCT cooperative learning on patriotism. The results of the descriptive analysis are interpreted through mean, median, mode, standard deviation, variance, minimum score and maximum score.

The data obtained is calculated average value and then interpreted into the criteria that have been determined and determined the percentage. Next, an inferential analysis is carried out with regard to drawing conclusions about the whole data.

Inferential analysis is used to test research hypotheses regarding the attitude of patriotism. Before testing the research hypothesis, an analysis prerequisite test is conducted which includes a normality test and a homogeneity test.

Normality test is used to determine whether the research data is normally distributed or not. This is important to know related to the accuracy of the selection of statistical tests to be used. The manual calculation that can be used in this normality test is the Liliefors method. This method is used if the data is not in the classified data frequency distribution. At each data X1 is changed to Z1 with transformation. The stages of the method are as follows:

$$
\begin{aligned}
& \text { Hypothesis } \\
& \mathrm{H} 0=\text { data normally distributed } \\
& \mathrm{H} 1=\text { data not normally distributed } \\
& \text { Significance level a }=5 \% .
\end{aligned}
$$

Test normality in this study using the Kolmogorov-Smirnov method with the help of SPSS 16.0 for Windows. The criterion in testing is if the significance value is greater than 0.05 then the data is normally distributed ( $\mathrm{H} 0$ is accepted), conversely if the significance value is less than 0.05 then the data is not normally distributed (H0 is rejected).

After the normality test, homogeneity testing is carried out in order to find out whether the experimental group and control group data have the same variance or not. This test is carried out on the results of the pretest and posttest attitude of patriotism . The hypothesis proposed to test to test population homogeneity is as follows: 
H0: samples come from populations that have the same / homogeneous variance

H1: the sample is not from a population that has the same / homogeneous variance

The test criteria are if the significance is $>0.05$ then $\mathrm{HO}$ is accepted and vice versa if the significance is $<0.05$ then $\mathrm{H} 0$ is rejected. Homogeneity test calculations are performed with the SPSS 16.0 for Windows program.

Analysis prerequisite tests are used to obtain data that are normally distributed and homogeneous. After the analysis prerequisites are fulfilled, the hypothesis test is continued

Univariant test to analyze each variable of the research results. The purpose of univariant analysis is to explain or describe the characteristics of each research variable. This variant test used in this study is the independent samples $t$ test to determine the effect of the use of each independent variable on the dependent variable. The testing criteria in this univariant test are that $\mathrm{H} 0$ is accepted if sign $>0.05$ and $\mathrm{H} 0$ is rejected if sign $<0.05$. Univariant tests were performed using SPSS 16 for windows.
Multivariate testing was conducted on the results of the experimental group 1 test, the experimental group 2, and the control group, used to analyze the influence of the VCT learning model on the attitude of students' homeland in grade IV elementary schools in the Nusantara Karangmoncol Purbalingga cluster.

Multivariate test was carried out with the help of SPSS 16.0 for Windows with a significance level of 0.05 . The decision criteria with $\alpha=0.05$ are $\mathrm{H} 0$ rejected if tcount $>\mathrm{t}$ table or significance $<0.05$.

\section{Result and Discussion}

After learning and testing the students, the results of the student's homeland love test results are obtained, which is then performed analisically. Data analysis consists of descriptive analysis and inferential analysis as follows.

Descriptive analysis is used to analyze data by describing or describing data that has been obtained from the results of pre-test and post-test in the control and experimental groups. You can see in Table 1.

Table 1

Pretest descriptive analysis test results

\begin{tabular}{|c|c|c|c|c|c|}
\hline \multicolumn{7}{|c|}{ Descriptive Statistics } \\
\hline Information & $\mathrm{N}$ & Min & Max & The mean & Std. Deviation \\
\hline VCT & 30 & 85.0 & 101.0 & 93.6333 & 4.72326 \\
\hline Control & 22 & 84.0 & 99.0 & 89.7727 & 4.24188 \\
\hline Control & 20 & 82.0 & 102.0 & 90.3500 & 5.69649 \\
\hline Valid N & 20 & & & & \\
\hline
\end{tabular}

Based on the above table, it can be seen in the initial test of the VCT experimental group that the highest score on the attitude of love for the motherland is 101 and the lowest is 85 , the average value of $(\mathrm{X})$ in the initial test for the attitude of love in the country is 93.6333, the standard deviation $(\mathrm{Sd})=4.72326$. In the initial test of the control group the highest value on the attitude of love for the homeland is 99 and the lowest is 84 , also obtained the average value of (X) initial test of the attitude of love for the homeland is 89.7727 , the standard deviation $(\mathrm{Sd})=4.24188$. While the initial test of the control group the highest value on the attitude of love this homeland is 102 and the lowest is 82, also obtained the average results of the value $(\mathrm{X})$ initial test of attitude of homeland love is 90.3500 , the standard deviation $(\mathrm{Sd})=5.69649$.

You can see "Comparison of the Average Pretest Value of the Experiment and Love Attitude Control Group of the Motherland" in Fig. 1.

The picture Fig. 1. above shows that on average the attitude of love for the homeland, VCT experimental group had an average value higher than the comparison with control group. You can see "Postest descriptive analysis test results" in Table 2.

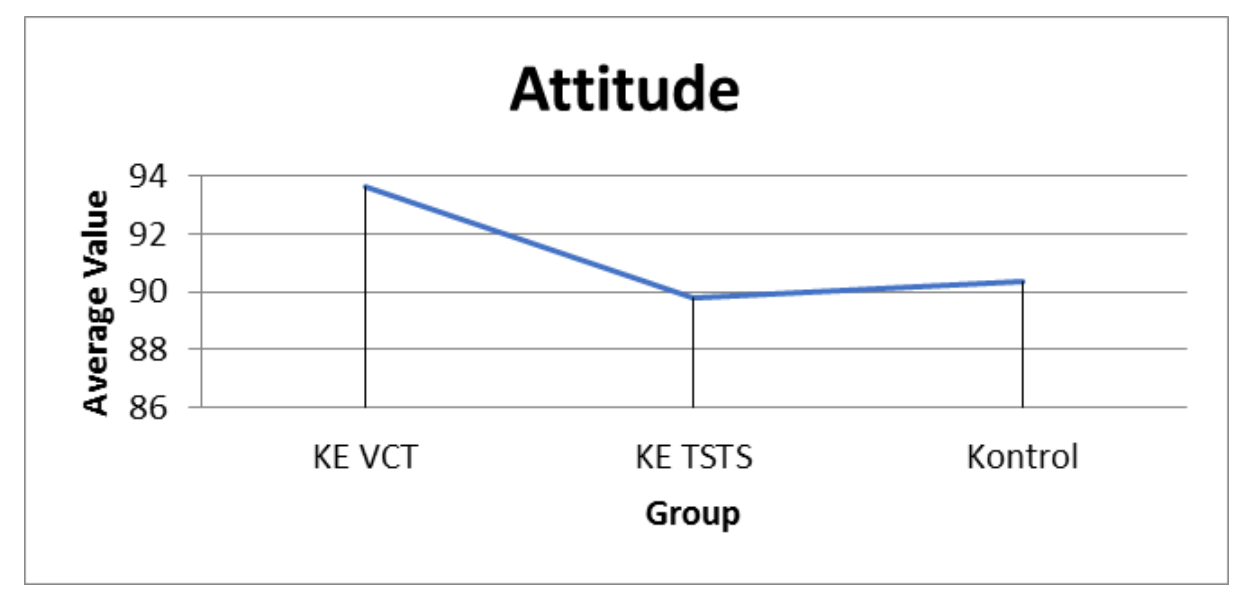

Fig. 1. Comparison of the Average Pretest Value of the Experiment and Love Attitude Control Group of the Motherland 
Postest descriptive analysis test results

\begin{tabular}{|c|c|c|c|c|c|}
\hline \multicolumn{7}{|c|}{ Descriptive Statistics } \\
\hline Information & $\mathrm{N}$ & Min & Max & The mean & Std. Deviation \\
\hline VCT & 30 & 106 & 121.00 & 114.9 & 3,62320 \\
\hline Control & 22 & 103 & 121.00 & 110.36 & 4.79628 \\
\hline Control & 20 & 77 & 112.00 & 100.95 & 9.29332 \\
\hline Valid N & 20 & & & & \\
\hline
\end{tabular}

Based on the table above, it can be seen in the initial test of the VCT experimental group that the highest value on the attitude of love for the motherland is 121 and the lowest is 106 , the average value of $(\mathrm{X})$ in the initial test for the attitude of love in the country is 114.9, the standard deviation $(\mathrm{Sd})=3.6232$. In the initial test of the control group the highest value on the attitude of loving the motherland is 121 and the lowest is 103, also obtained the average value of (X) initial test of the attitude of loving the motherland is 110.3636 , the standard deviation $(\mathrm{Sd})=4.79628$. While the initial test of the control group the highest value on the attitude of patriotism is 121 and the lowest is 103 , also obtained the average value of (X) initial test of patriotism is 110.3636 , the standard deviation $(\mathrm{Sd})=4.79628$.

You can see "Comparison of Postest Average Value of Experiment and Control Group Understanding Concepts" in Fig. 2.

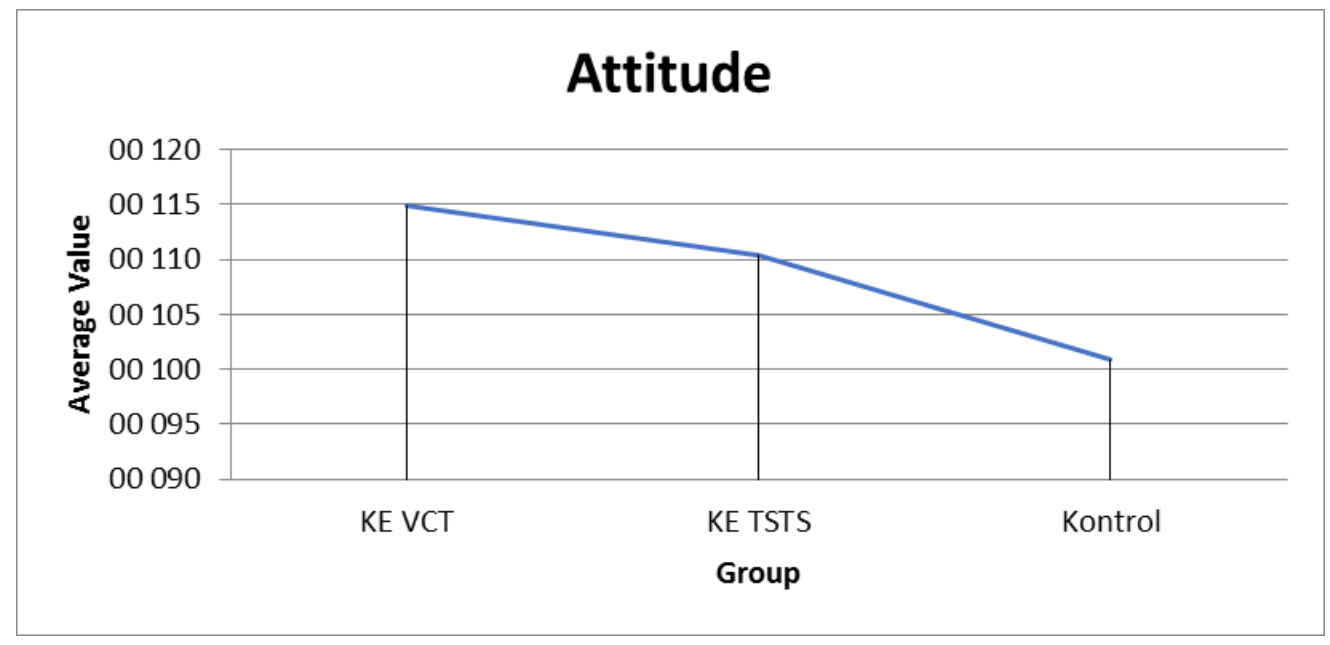

Fig. 2. Comparison of Postest Average Value of Experiment and Control Group Understanding Concepts

The picture above shows that on average both in the attitude of love for the homeland and understanding concepts VCT experimental group had an average value higher than the control group.

Inferential analysis is used to test research hypotheses regarding the understanding of concepts and attitudes of patriotism. Before testing the research hypothesis, an analysis prerequisite test which includes a normality test and a homogeneity test is used to test the research hypothesis regarding the understanding of concepts and attitudes of patriotism. Before testing the research hypothesis, an analysis prerequisite test is con- ducted which includes a normality test and a homogeneity test

The normality test of the pretest score and the posttest score used the Kolmogorov-Smirnov test which was conducted on students' understanding of concept data in the experimental and control classes. The results of the analysis of the normality test are as follows:

Test the normality of the results of the experimental and control group pretests. The normality test is carried out using SPSS 23 software, using the Kolmogorov-Smirnov test. The results of the KolmogorovSmirnov test for both.

The results of the normality test with Kolmogorov-Smirnov

\begin{tabular}{|c|c|c|c|c|}
\hline Information & $\mathrm{N}$ & Statistical Test & Asymp. Sig. (2-tailed) & Distribution \\
\hline VCT & 30 & .92 & $.200 \mathrm{c}, \mathrm{d}$ & Normal \\
\hline Control & 22 & .159 & $.15 \mathrm{cc}$ & Normal \\
\hline Control & 20 & .121 & $.200 \mathrm{c}, \mathrm{d}$ & Normal \\
\hline
\end{tabular}

Based on the table above that the calculation of the pretest score of the Love Attitude of the Homeland experimental class students obtained significance values of 0.200 and 0.155 , while the significance value of the 
Attitude of Love of the Homeland control class students also amounted to 0.200 .

The normality test is carried out using SPSS 23 software, using the Kolmogorov-Smirnov test. The results of the Kolmogorov-Smirnov test for both groups are presented in Table 4.
Based on the table above that the calculation of the posttest score data of the Love Attitude of the Homeland experimental class students obtained significance values of 0.200 and 0.080 , while the significance value of the Attitude of Love of the Homeland of the control class students also amounted to 0.070 .

Table 4

The results of the normality test with Kolmogorov-Smirnov

\begin{tabular}{|c|c|c|c|c|}
\hline Information & $\mathrm{N}$ & Statistical Test & Asymp. Sig. (2-tailed) & Distribution \\
\hline VCT & 30 & .104 & $.200 \mathrm{c}, \mathrm{d}$ & Normal \\
\hline Control & 22 & .174 & $.080 \mathrm{c}$ & Normal \\
\hline Control & 20 & .185 & $.070 \mathrm{c}$ & Normal \\
\hline
\end{tabular}

The homogeneity test of the pretest score and the posttest score uses the Levene test which is conducted on the data of students' homeland love attitude in the experimental and control classes. The results of the analysis of the homogeneous test are as follows.

Homogeneity test of group pretest results Homogeneity test was carried out using SPSS 23 software, using Levene test. The results of the Levene test of the two groups are presented in Table 5.

Based on the table above, the calculation of the pretest score of the homeland love attitude of the experimental class and control class students obtained a significance value of 0.403 . Because the significance value of the homeland love attitude of the experimental class and control class students is greater than 0.05 , it can be concluded that the pretest score data of students' concept understanding in the experimental class and the control class have the same variance (homogeneous).

Homogeneity test was carried out using SPSS 23 software, using Levene test. Levene test results for the two groups are presented in Table 6.

Based on the table above, the calculation of the posttest score data of the love attitude of the homeland students of the experimental class and the control class obtained a significance value of 0.101 . Because the significance value of the concept understanding of the experimental class and the control class is greater than 0.05 , it can be concluded that the posttest score data of students' homeland love attitude in the experimental class and the control class have the same variance (homogeneous).

After a normality test and a homogeneity test were obtained, the data were normally distributed both in the experimental group and the control group, then the homogeneity was also fulfilled because the two samples based on calculations turned out to be included in the criteria of normally distributed and homogeneous samples. Next, analyze the results of the hypothesis test using the following test.

Multivariate testing was conducted on the results of the experimental group test, control group 1, and control group 2 , used to analyze the effect of the VCT learning model on students' homeland attitudes in grade IV elementary schools in Nusantara Karangmoncol Purbalingga. You can see "Multivariate Analysis Results" in Table 7.

Table 5

Homogeneity test results with Levene test

\begin{tabular}{|c|c|c|c|c|}
\hline \multicolumn{5}{|c|}{ Test of Homogeneity of Variances } \\
\hline Information & Levene Statistics & df1 & df2 & Sig. \\
\hline Attitude & .921 & 2 & 69 & .403 \\
\hline
\end{tabular}

Table 6

Homogeneity test results with Levene test

\begin{tabular}{|c|c|c|c|c|}
\hline Information & Levene Statistics & df1 & df2 & Sig. \\
\hline Attitude & 1,917 & 2 & 69 & .101 \\
\hline
\end{tabular}

Table 7

Multivariate Analysis Results

\begin{tabular}{|c|c|c|c|c|}
\hline \multirow{3}{*}{ Information } & Sum of Squares & F & Sig. \\
\hline \multirow{3}{*}{ Attitude } & Between Groups & 2351,870 & 32,394 & .000 \\
\cline { 2 - 5 } & Within Groups & 2504,741 & & \\
\cline { 2 - 5 } & Total & 4856,611 & & \\
\hline
\end{tabular}


Based on the table above it can also be seen that there is a significant difference between the attitude of patriotism between the learning of VCT models and conventional learning as indicated by the value of sig. $=0,000$ or $<0.05$. This means that the research hypothesis that reads: There is a difference in the attitude of patriotism between the learning of the VCT model and conventional learning in class IV SD throughout the Karangmoncol Purbalingga Archipelago group was accepted.

VCT is a learning model that helps someone to clarify their values. If someone has managed memperje 1 as its own value, it will produce a change in behavior. VCT encourages someone to think critically and systematically about the values that exist in society or the environment. Students who learn with the VCT model are trained to find the values that exist in themselves. Learners will consider the values they have associated with existing values in society

Learning with VCT is based on the principle of moral relativity $[5,3]$. That is, VCT is a value learning model that shows that people's opinions are not the same. This is very much influenced by the different stages of moral development of people. Students are directed to appreciate the relativity of values through learning that contains moral dilemmas. Therefore it is very appropriate if VCT is used to shape students' tolerance attitude. Tolerance is behavior that leads to mutual respect for differences.

The results showed that posttest homeland love attitude between the VCT experimental group and the con- trol group there was a significant difference. Likewise, the understanding of the posttest concept between the VCT experimental group and the control group contained significant differences.

\section{Conclusion \& Suggestion}

The independent $t$ test results showed that the posttest homeland love attitude between the VCT experimental group and the control group contained significant differences. As for the results of the multivariate test with ANOVA shows that there is a significant difference between students' understanding of concepts between learning VCT models and conventional learning as indicated by the value of sig. $=0.001$ or $<0.05$. There is a significant difference between the attitude of patriotism between the learning of VCT models and conventional learning which is indicated by the value of sig. $=0,000$ or $<0.05$.

To elementary school class teachers, especially class IV, so that in conducting learning activities that can pay attention to the attitude of love students homeland so that children do not get bored and enthusiastic in following the learning process by applying the VCT method.

To the school in order to be more able to encourage teachers to always develop themselves in the mastery and application of new learning methods especially in thematic lessons in Elementary Schools so that the understanding of concepts and attitudes of students' homeland love can be improved.

\section{References}

1. Wijayanti A. T. Implementasi Pendekatan Values Clarivication Technique (VCT) dalam Pembelajaran IPS di Sekolah Dasar // SOCIA: Jurnal Ilmu-Ilmu Sosial. 2013. Vol. 10, Issue 1. P. 72-79.

2. Samani M., Hariyanto M. S. Konsep dan model pendidikan karakter. Bandung: Remaja Rosdakarya, 2012.

3. Saksono I. G., Dwiyanto D. Faham keselamatan dalam budaya Jawa. Yogyakarta: Ampera Utama, 2012.

4. Zajonc A. Love and Knowledge: Recovering the Heart of Learning Through Contemplation // Teachers College Record. 2006. Vol. 108, Issue 9. P. 1742-1759. doi: https://doi.org/10.1111/j.1467-9620.2006.00758.x

5. Attarian A. Integrating Values Clarification into Outdoor Adventure Programs and Activities // Journal of Physical Education, Recreation \& Dance. 1996. Vol. 67, Issue 8. P. 41-44. doi: https://doi.org/10.1080/07303084.1996.10604837

6. Kirschenbaum H. Clarifying Values Clarification: Some Theoretical Issues and a Review of Research // Group \& Organization Studies. 1976. Vol. 1, Issue 1. P. 99-116. doi: https://doi.org/10.1177/105960117600100109

7. Oliha J., Audu V. I. Effectiveness of value clarification and self-management techniques in reducing dropout tendencies among secondary school students in Edo State // European Journal of Education and Development Psychology. 2015. Vol. 3, Issue 1. P. 1-13.

8. Edwards A. W. Values clarification as a therapeutic process // A paper presented in NACSW Convention Grand Rapids. 2005.

9. Brady T. F., Oliva A. Statistical Learning Using Real-World Scenes // Psychological Science. 2008. Vol. 19 , Issue 7. P. 678-685. doi: https://doi.org/10.1111/j.1467-9280.2008.02142.x

10. Gray J. R. Value Clarification: a Step Towards Technological Literacy // Bulletin of Science, Technology \& Society. 1987. Vol. 7, Issue 1-2. P. 197-205. doi: https://doi.org/10.1177/027046768700700134

11. Kirschenbaum H. Values clarification in counseling and psychotherapy: Practical strategies for individual and group settings. New York: Oxford University Press, 2013. doi: https://doi.org/10.1093/acprof:oso/9780199972180.001.0001

12. Not all anxious individuals get lost: Trait anxiety and mental rotation ability interact to explain performance in map-based route learning in men / Thoresen J. C., Francelet R., Coltekin A., Richter K.-F., Fabrikant S. I., Sandi C. // Neurobiology of Learning and Memory. 2016. Vol. 132. P. 1-8. doi: https://doi.org/10.1016/j.nlm.2016.04.008

13. Naim N. Character buliding optimizing the role of education in the development of science \& national character formation. Yogyakarta: Ar - Ruzz Media, 2012.

14. Patriotism and Nationalism in Music Education / D. G. Hebert, A. Kertz-Welzel (Eds.). Ashgate Publishing, 2016.208 p. doi: https://doi.org/10.4324/9781315599731

15. The influence of nationalism and national identity on well-being of Bulgarian and Romanian youth / Dimitrova R., Buzea C., Ljujic V., Jordanov V. // Studia UBB Sociologia. 2013. Vol. 58, Issue 1. P. 69-86. 
16. Muhaimin M. Implementation of the value clarification model in developing the emulation competence of the childhood behavior of the Prophet Muhammad // Journal of Islamic Education and Institutions. 2015. Vol. 10, Issue 1. P. 80-96.

17. Azwar S. Konstruksi tes kemampuan kognitif. Yogyakarta: Pustaka Pelajar, 2016.

18. Sudjana N. Assessment of the results of the teaching and learning process. Bandung: PT Remaja Rosdakarya, 2005.

Received date 20.08.19

Accepted date 12.09.2019

Published date 30.09.2019

Anantama Dewantoro, Primary Education, Postgraduate Program, Universitas Negeri Yogyakarta, Colombo str., 1, Karang Malang, Caturtunggal, Depok District, Sleman Regency, Daerah Istimewa Yogyakarta, Indonesia, 55281 E-mail: anantamaid@gmail.com

Kus Eddy Sartono, Faculty of Education, Universitas Negeri Yogyakarta, Colombo str., 1, Karang Malang, Caturtunggal, Depok District, Sleman Regency, Daerah Istimewa Yogyakarta, Indonesia, 55281

E-mail: kus_edisartono@uny.ac.id 